\title{
Studijní a pracovní strachy mladých dospělých
}

\section{School Fears and Employment-related Fears in the Young Adulthood Period}

\author{
Anežka Kohoutová', Lenka Lacinová \\ 'Katedra psychologie, Fakulta sociálních studií, Masarykova \\ univerzita $\vee$ Brně \\ ${ }^{2}$ Institut výzkumu dětí, mládeže a rodiny Fakulta sociálních \\ studií, Masarykova univerzita v Brně
}

Psychologie a její kontexty 11 (1), 2020, 69-87

https://doi.org/10.15452/PsyX.2020.11.0005

UNIVERSITY OF OSTRAVA

\begin{abstract}
Abstrakt Cílem studie bylo prozkoumat možné faktory, které se vztahují k výskytu subjektivně prožívaných studijních a pracovních strachů v období mladé dospělosti. Vzorek tvořilo 303 respondentů z projektu „Cesty do dospělosti“ (83,8 \% žen, průměrný věk = 24 let; $\operatorname{Min}=19,08$, Max = 32). Metoda. Data byla získávána pomocí online dotazníků. Výpovědi o studijních a pracovních straších byly získávány metodou volných výpovědí. Dále byly administrovány tyto dotazníky - GIDS, The Academic Self-Efficacy Scale, CDSE-SF, Perception of Parental Autonomy-Support and Control Scale. Z výsledků regresní analýzy vyplývá, že existuje vztah mezi výskytem studijních strachů, akademického vědomí vlastní účinnosti, podporou autonomie ze strany otce, pohlavím a závazkem ke studiu. Dále byl detekován vztah mezi výskytem pracovních strachů a závazkem $\mathrm{k}$ práci, pocitovanou kontrolou ze strany otce, pracovním úvazkem a zaměstnáním, které souvisí s plánovanou profesí respondenta. Limitem studie je především velká převaha žen ve výzkumném souboru.
\end{abstract}

Klíčová slova Studijní strachy, pracovní strachy, mladí dospělí.

Abstract Objectives. The study aimed to examine the relationship between selected factors and the presence of school and employment-related fears in young adults. Sample. Overall, the study sample comprised 303 respondents from the longitudinal project "Cesty do dospělosti" [Paths to Adulthood] (83.8 \% were women; the average age of the respondents was 24 years $\mathrm{SD}=1.47 ; \mathrm{Min}=19.08, \mathrm{Max}=32$ ). Method. Questionnaire data 
were collected on-line. The study used self-rating scales (GIDS, The Academic Self-Efficacy Scale, CDSE-SF, Perception of Parental Autonomy-Support and Control Scale.). The school fears and the employment-related fears were collected by open-ended questions on fears. Results. The open-ended answers on fears were categorized into general categories, where the school fears were the second most frequented category and the employment-related fears represented the fifth most frequented category. Regression analysis indicated that the gender, academic self-efficacy, perception of autonomy support from the father and commitment to study were significant predictors for the presence of school fears. Perception of father's control, having an employment (mainly one related to one's future profession) and commitment to one's job were found to be significant predictors for the presence of employment-related fears.

The results reveal that the presence of school fears was more related to the perception and evaluation of one's own learning abilities, self-efficacy, and commitment to study. The presence of employment-related fears was more related to work experience - it was the strongest predictor. In terms of work experience, the most important influence was the experience of employment related to one's future profession. The perception and evaluation of one's own abilities did not have a significant effect on the presence of employment-related fears. Interesting was the relationship between perceived father's autonomy support and control and the categories of fears. Higher autonomy support from the father increased the chance of school fears presence. It may be explained by a higher degree of perceived responsibility for study and the fear of disappointing parents. Higher autonomy control from the father reduced the chance of employment-related fears presence, which can be explained by the reduced responsibility for work decisions and the overall lower motivation to explore the employment area. Based on the results, it is possible to better understand the context of school and employment-related fears - the identified findings are fully consistent with the developmental challenges and characteristics of the young adulthood period. Limitations. The study impact is limited by the sample structure: the sample was over-represented by women, students, and respondents of older age group.

Keywords school fears, employment-related fears, young adulthood. 


\section{Problém}

O generaci současných dvacátníků se někdy v tisku mluví jako o generaci, která nechce dospět, která se snaží zbavit zodpovědnosti a která si vlastně „stále užívá“ (viz titulky: Proč jsou mladí Češi líní a nechtějí pracovat?;' Není komu předávat rodinné firmy. Děti nechtěji převzít odpovědnost ${ }^{2}$ ). Realita je samozřejmě mnohem složitější. Poměrně odlišně toto období reflektují samotní aktéríi. Otázkou životních cílů a plánů se zabývaly Weier a Lee (2016). Studenti ( $\mathrm{N}=518$, věk $\mathrm{M}=19$ ) popisovali, jak si představují život, až jim bude 40 let. Více než 90 \% z nich chtělo vstoupit do manželství a mít děti a uspokojivou práci-většina $\mathrm{z}$ nich také již měla jasno jakou, pouze 6 \% studentů si svou volbou stále nebylo jisto. Pro studenty bylo důležitější, aby si našli práci, která je bude naplňovat a bude je bavit, spíš, než aby se jednalo o dobře placené zaměstnání. Chow, Galambos a Kram (2017) se zaměřili na vnímání pracovních hodnot u mladých lidí ( $\mathrm{M}=23$ let, $\mathrm{N}=373$ ), největší důraz kladli na možnost vlastní seberealizace. Autoři výsledky srovnávají s obdobnými studiemi, prováděnými s generací současných čtyřicátníků - ti kladli větší důraz na stabilitu a finanční stránku zaměstnání. Období tř̌etího decennia lze tedy charakterizovat jako etapu, ve které mladí lidé dokončují studium, hledají vhodného partnera a vhodnou práci. Určitým posunem oproti dřivější generaci ale je, že dnešní mladí lidé hledají práci, která je bude bavit a přinese jim možnost seberealizace. Obdobný postoj se promítá též do př́istupu ke studiu, na který jsou mladými lidmi kladeny též vyšší nároky - je pro ně důležité, aby studovali obor, ve kterém vnímají možnosti seberealizace a který vnímají jako zajímavý (Gardner $\&$ Eng, 2005). Další změnou také je, že proces hledání a získání práce již není lineární (Ranta, Dietrich, \& Salmela-Aro, 2014).

Hledání vhodné profesní cesty je spojeno také s různými prožitky strachu. Konkrétní oblasti strachu se v průběhu vývoje proměňují a odráží stresující úkoly, které jsou spjaty s vývojovými stadii (King et al., 1989). Specifické strachy lze tedy vnímat jako vývojově podmíněné strachy, které se objevují v určitých vývojových stádiích a trvají pouze omezenou dobu (Muris et al., 2002). Lze tedy očekávat, že pro období třetího decénia budou typické kromě partnerských strachů, právě strachy spojené se studiem a prací. Ranta, Dietrich a Salmela-Aro (2014) se ve své studii (N = 1052, věk 20-23 let) zaměřili na současné obavy a cíle mladých lidí. Projevilo se zde velice úzké propojení strachů a cílů-dalo se říci, že prožívané strachy téměř přesně reflektovaly životní plány respondentů. V obou věkových kohortách byly na prvním místě obavy a cíle spojené se vzděláním a zaměstnáním. Autoři se domnívají, že konkrétní obavy, kterým lidé čelí, vedou k nastavení takových cílů, které by měly dané obavy řešit. Obavy jsou do určité míry motivačním faktorem. Studijní a pracovní strachy $\mathrm{v}$ období třetího décenia by tedy měli uvádět ti mladí lidé, kteří v současné době řeší jak potíže $v$ těchto oblastech, tak též ti, kteří mají své současné životní cíle s těmito oblastmi spojené. Hlavním cílem předkládané studie tedy je zjistit,

https://echo24.cz/a/i6NNe/proc-jsou-mladi-cesi-lini-a-nechteji-pracova

2 https://www.denik.cz/ekonomika/neni-komu-predavat-rodinne-firmy-deti-nechteji-prevzit-odpovednost-20170830.html 
zda existují faktory a charakteristiky, které predikují u mladých lidí ve třetí dekádě života výskyt subjektivně prožívaných studijních a pracovních strachů.

Strachy související se školou procházejí v průběhu vývoje změnami a jejich výskyt a intenzita stoupá s přibývajícím věkem. Jedním $z$ důvodů je výskyt relevantních událostí, jako je přechod na vyšší formu vzdělávání a přijímací zkoušky (Gullone \& King, 1993). V adolescenci se také mění význam školy, která se stává důležitým prostorem pro seberealizaci a srovnávání se s druhými (Michalčáková, 2007). Mezi nejčastěji prezentované školní strachy v období adolescence patří strach ze známek, vysvědčení, písemek a školy jako takové (Hejlová, 2005; Michalčáková, 2007). Konkrétní podobou školních strachů v období třetího decénia se zabývala Volková (2015). V otevřených výpovědích studentů ve věku 19-29 let $(\mathrm{N}=500)$ přetrvával strach ze školního výkonu, strach ze školního hodnocení se však oproti období adolescence dostával výrazně do pozadí. Strach ze známek se ve volných výpovědích nevyskytl vůbec. Studenti uváděli spíše strach ze zkoušek jako takových, dále strach $z$ nedostudování a také ze špatné volby studia. Obávali se, zda jim studium v budoucnu k něčemu bude a zda je bude naplňovat a bavit. Školní výkon tedy přestává být důležitý $\mathrm{z}$ hlediska srovnávání se s druhými, stává se spíše prostředkem k získání zaměstnání a titulu jako takového. Strachy spojené se zaměstnáním se začínají objevovat již v adolescenci, významnější nástup je zaznamenán až v období tř̌etího decénia (Michalčáková, 2007). Obsahem pracovních strachů v mladé dospělosti ( $M=24$ let, $\mathrm{N}$ =642) se zabývaly Volková, Lacinová, Neužilová Michalčáková a Dušková (2016). Jednalo se očtvrtou nejčastěji uváděnou kategorii strachů, obsahovaly obavy spojené se současnou či budoucí prací, dále strach $\mathrm{z}$ nenalezení vhodného povolání, kde by jedinec mohl uplatnit naučenéa zároveň se seberealizovat a strachy ze ztráty zaměstnánía kariérního neúspěchu.

Celkově, ženy uvádí více strachů a jejich intenzivnější prožitek než muži, a to ve všech vývojových obdobích (Gullone, 2000; Matud, 2004). Tento rozdíl je částečně ovlivněn různými genderovými očekáváními, dívky jsou společností vedeny k otevřenějšímu vyjadřování strachů, ženy jsou ochotnější o strachu vypovídat (Muris, Meesters, \& Knoops, 2005). V dospělosti dochází $\mathrm{k}$ rozdílům v obsahu strachů-ženy uvádějí více strachů spojených s každodenním fungováním, strachy o blízké a o zdraví. Muži naopak uvádí více strachů spojených se zaměstnáním a financemi, než ženy (Matud, 2004). Ve studii Volkové a Duškové (2015) byl nejvýraznější rozdíl v intenzitě strachů u školních a rodičovských strachů, ženy byly v těchto kategoriích výrazně strachuplnější než muži. V oblasti studijních strachů lze tedy očekávat, že budou ženy uvádět strachů více, než muži. V oblasti pracovních strachů by tento rozdíl neměl být tak velký a mohl by být dokonce opačný. Na druhou stranu je třeba brát v úvahu také specifikum konkrétního období, ženy jsou ve věku, který je společností spojován se zakládáním rodiny, jejich pozice na pracovním trhu je tedy ohroženější (Valentová, 2004).

Ujasnit si vlastní pracovní identitu je dalším $z$ vývojových úkolů třetího decénia. Formování pracovní identity má svůj počátek již v rámci samotného vzdělávacího procesu, kdy studenti zjištují, co je baví a také to, jaké jsou jejich reálné možnosti. Studijní a pracovní identita jsou dva úzce provázané koncepty, škola má významný vliv na rozvoj profesního uvažování (Porfeli \& Lee, 2012). Bosma a Kunnen (2001) vývoj studijní a pracovní 
identity vnímají jako proces, přičemž vychází z Marciova pojetí (1993), dle kterého se ustavování identity odehrává prostřednictvím explorace a uzavírání závazků. Bosma (1985) pojímá exploraci jako proces aktivního hledání a závazek popisuje jako vědomou zaangažovanost, to, kolik jsou lidé ochotni obětovat, aby dosáhli svého cíle, popřípadě se ho vzdali. Závazek v kariérní identitě je tedy spojen s vyššíjistotou při kariérním rozhodování a také s vyšším zaangažováním a uspokojením z práce (Kidd 8 Green, 2006). Obdobně je tomu také se studijní identitou, kdy vyšší síla závazku ke studiu a explorace studia pozitivně souvisí se studijní spokojeností a jistotou, a dále také odráží vyšší studijní zaangažovanost (Vijaykumar \& Lavanya, 2015). Je pravděpodobné, že proces utváření studijní a pracovní identity bude souviset též s uváděnými strachy v dané oblasti. Vzhledem $\mathrm{k}$ tomu, že vyšší míra explorace a závazku je spojena s vyšší jistotou, zároveň však také vyšší zaangažovaností, je těžké odhadnout, jaký bude mít na výskyt strachů vliv. Vyšší jistota v rozhodování o kariéře by měla výskyt strachů spíše snižovat, zatím co zaangažovanost se může v podobě vyššího významu a motivace promítnout do zvýšeného výskytu strachů. Utváření studijní identity je v tomto období výrazně delší, než je tomu u identity pracovní. Znamená to, že by ve studijní oblasti mohl být tento proces více konsolidován a být spojen s vyšší jistotou v rozhodování. Je možné očekávat, že v oblasti studijní bude vysoký závazek výskyt strachů snižovat, protože bude minimalizovat nejistotu spojenou se špatnou volbou studia. V oblasti práce by naopak vyšší závazek mohl souviset s vyšším výskytem strachů, nebot pracovní závazek pravděpodobně může zvyšovat vlastní nároky na pracovní výkon a strach $\mathrm{z}$ př́padného pracovního selhání.

Studijní a pracovní strachy a jejich výskyt mohou souviset s mírou vědomí vlastní účinnosti. Bandura (1997) jej popsal jako vnímání vlastních schopností uspořádat a vykonat akci tak, aby vedla $\mathrm{k}$ dosažení předem stanovených cílů. Vědomí vlastní účinnosti se vztahuje k budoucnosti, je ale podmíněno minulými výkony, vlastní či zprostředkovanou zkušeností. Vnímaná účinnost ovlivňuje mnoho aspektů života, je např. prediktorem akademického úspěchu, akademické či pracovní aspirace (Bandura, Barbaranelli, Caprara, \& Pastorelli, 2001). Vnímaná akademická účinnost je přesvědčení studentů o tom, že jsou schopni zvládnout požadavky a úkoly se studiem spojené. Má pozitivní vliv na studijní zaangažovanost, na studijní výkon a studijní úspěch, souvisí s důslednější studijní přípravou a zvyšuje zájem o studijní výsledky (Betz \& Hackett, 1986; Vuong, Brown-Welty, \& Tracz, 2010). Vzhledem k vyššímu zaměření na studijní oblast a výsledky lze tedy očekávat, že vyšší akademická účinnost bude spojena s vyšším výskytem studijních strachů. Při hledání vhodné profese je možno mluvit v souvislosti s konstruktem vědomí vlastní účinnosti o sebeúčinnosti v kariérním rozhodování se. Tímto pojmem je zastřešen souhrn faktorů, které přispívají $\mathrm{k}$ rozvoji kariérní identity. Zkoumá přesvědčení o vlastní schopnosti úspěšného dokončení konkrétních úkolů v souvislosti s hledáním vhodné profese. Několik studií potvrdilo, že vyšší sebeúčinnost v kariérním rozhodování snižuje profesní nerozhodnost a přispívá k vyšší jistotě a úspěchu v procesu tvorby kariéry (Creed \& Patton, 2003; Rogers, Creed, \& Glendon, 2008). Je tedy pravděpodobné, že vysoká míra sebeúčinnosti v kariérním rozhodování se bude spojena s nižším výskytem pracovních strachů. 
Období třetího decénia může být pro mnohé obdobím, kdy se musí vyrovnat se ztrátou jistého finančního př́jmu od rodičů. U některých může tento fakt vést k předčasnému nástupu do zaměstnání, na druhou stranu se některým studentům daří obě pozice skloubit. Těmto mladým lidem se tak ale zužuje množství možností-musí volit takové studium, které lze se zaměstnáním sladit. Monsey, Vandehey a Diekhoff (2013) porovnávali dvě skupiny studentů ( $\mathrm{N}=110,18-27$ let), a to studenty, kteří kromě studia měli též zaměstnání, a pouze studující studenty. $\mathrm{V}$ míře depresivních symptomů, ani ve školních výsledcích nebyl mezi skupinami výrazný rozdíl, pracující studenti ale zažívali stavy spojené s vyšší úzkostí a stresem. Je tedy možné očekávat, že studenti, kteří zároveň pracují, budou uvádět více studijních strachů než studenti, kteří se plně věnují pouze studiu.

Konstam a Lehmann (2011) reflektují posun v hledání vhodného zaměstnání u mladých lidí v posledním desetiletí. Rozhodování a výběr pracovní kariéry vnímají jako sérii výběrů, které člověk činí v průběhu svého životního vývoje, ne jako jedno závazné rozhodnutí, které člověk musí udělat v mládí. Lidé tedy dnes spíše „dělají kariéry“ než jednu kariéru. V souvislosti se společenským vývojem je totiž hledání toho, co člověku vyhovuje, více tolerováno a očekáváno. Autoři spíše rozdělují mladé dospělé, kteří mění práce bezcílně, od těch, kteří zkouší různá pracovní místa s určitým cílem, či záměrem. U druhé skupiny lze očekávat větší zodpovědnost a jistější přístup v kariérním rozhodování se. Kariérní rozhodování je spojeno také s objevováním vlastních schopností a zájmů. Konstam a Lehmann (2011) proto zdůrazňují význam volnočasových aktivit a různých pracovních zkušeností, díky kterým mohou mladí lidé experimentovat a poznávat sami sebe. V empirické studii (64 studentı̊, 25-30 let) byl tento předpoklad podpořen. Jak volnočasové aktivity, tak také konkrétní pracovní zkušenosti výrazně přispívají k úspěšnému procesu kariérního rozhodování (zejména k vyššímu pocitu jistoty). Proces kariérního rozhodování posouvají nejen zkušenosti s prací, která se váže $\mathrm{k}$ budoucí kariéře mladých lidí, ale také s prací, kterou mladí lidé vykonávají pouze pro výdělek (tento typ pracovních zkušeností převažuje zejména $\mathrm{v}$ počátku pracovní kariéry). I zde je umožněno mladým lidem lépe si uvědomit své možnosti, dovednosti a přání. Některé studie potvrzují, že se s přechodem do zaměstnání zlepšuje pocit osobní pohody, klesá prevalence rizikového chování a symptomy deprese (Schulman $\&$ Ben-Artzi, 2003). Jedním z vysvětlení této změny je právě redukce stresu spojená s kariérním rozhodováním a také strachu spojeného s možností najít odpovídající zaměstnání (Kenny \& Sirin, 2006). Buhlová (2007) ve své longitudinální studii zaměřené na přechod studentů $\mathrm{z}$ univerzity do zaměstnání ( $\mathrm{N}=101$, věk $\mathrm{M}=25,44)$ zaznamenala zlepšení pocitu osobní pohody jak v psychické, tak fyzické oblasti. Výraznější dopad má zaměstnání, které je vnímáno jako spojené s budoucí plánovanou profesí. Lze tedy předpokládat, že existence práce bude snižovat výskyt strachů spojených se zaměstnáním.

Na vývoji pracovní a studijní identity se také podílejí vztahy s rodiči. Existenci rodičovské podpory jako pozitivního faktoru v procesu přechodu $\mathrm{z}$ adolescence do dospělé role potvrzuje např. Desjardins a Leadbeater (2017), kteří se v šestileté longitudinální studii u 240 mladých dospělých (věk $M=19,43$ ) zaměřili na vliv rodičovské podpory a kontroly na jejich studijní a pracovní postoje a také na výskyt úzkostných a depresivních sympto- 
mů. Rodičovská kontrola a podpora se v průběhu sběru dat měnila, celkově však míra kontroly klesala s rostoucím věkem respondentů, zatímco míra podpory spíše stoupala. Vyšší rodičovská kontrola vedla $\mathrm{k}$ vyššímu výskytu úzkostných i depresivních symptomů, zatímco rodičovská podpora jejich výskyt naopak snižovala. $\mathrm{V}$ obou př́padech měla výraznější vliv podpora i kontrola ze strany matky (než otce), byla také výrazně častěji poskytována. U mladých žen byla podpora matky spojena s nižším výskytem akademických problémů a jejich lepším zvládnutím. Celkově lze říci, že pokud měly mladé ženy podporující matky, naučily se vyhledávat pomoc v případě potíží. Mladé ženy, které své matky nevnímaly jako podporující, řešily problémy většinou samy, což snižovalo jejich šanci na úspěch. U mladých mužů vedla vyšší mateřská podpora k lepšímu vnímání svých schopností a studijních i pracovních dovedností, tedy k lepšímu sebehodnocení. U obou pohlaví však vyšší rodičovská podpora vedla k celkově vyšší nezaměstnanosti. Ti respondenti, kteří vnímali vyšší podporu, měli méně často zaměstnání během studia a zůstávali déle nezaměstnaní. Autoři to vysvětlují tím, že je rodiče a ani okolnosti nenutí $\mathrm{k}$ tomu hledat si práci. Vyšší rodičovská kontrola vedla celkově k více problematickým postojům jak v oblasti studia, tak v oblasti zaměstnání. Respondenti s vysokou mírou rodičovské kontroly popisovali více problémů, obav a stresu v těchto oblastech, vnímali sami sebe jako méně schopné a zažívali méně úspěchů jak ve studiu, tak v práci. Význam rodičovské podpory pro zralý a úspěšný přístup k zaměstnání u mladých lidí ( $\mathrm{N}=100,22-29$ let) potvrzuje též Schulman s kolektivem (2016). U respondentů, kteří si byli jisti ohledně svých cílů a v profesní oblasti prokazovali dobrou schopnost sebereflexe a pracovního růstu, identifikovali vysokou míru rodičovské podpory a vědomí vlastní účinnosti.

Současná studie si klade několik cílů. Jedním cílem je prozkoumat vztah mezi vnímanou podporou a kontrolou ze strany rodičů ve třetí dekádě života a výskytem pracovních a studijních strachů. Dalším výzkumným cílem bude prozkoumat vztah mezi vědomím vlastní účinnosti, explorací a závazkem a pracovními a studijními strachy u mladých dospělých, dále prozkoumat souvislost mezi pohlavím respondentů a pracovními a studijními strachy. Poslední výzkumný cíl se týká prozkoumání vztahu mezi pracovním poměrem, a subjektivním hodnocením smysluplnosti práce a studia a výskytem studijních a pracovních strachů.

\section{Současná studie: Výzkumná otázka, hypotézy}

Výzkumná otázka: Mají vybrané proměnné - pohlaví, pracovní poměr, subjektivní vnímání práce a studia, podpora autonomie a kontrola ze strany rodičů, akademické vědomí vlastní účinnosti, sebeúčinnost v kariérním rozhodování se a explorace a závazek ke studiu a práci - souvislost se subjektivně prožívaným výskytem studijních a pracovních strachů u mladých lidí?

Předpokládáme, že:

- Nižší výskyt studijních strachů budou mít ti, kteří v současnosti pouze studují, oproti těm, kteří zároveň studují a pracují.

- Vyšší výskyt studijních strachů budou mít ženy oproti mužům. 
- Výskyt studijních strachů bude nižší u těch, kteří své studium vnímají jako přípravu na budoucí povolání.

- Vyšší výskyt studijních strachů, souvisí s vyšší mírou akademického vědomí vlastní účinnosti, s vyšší mírou rodičovské kontroly a nižší mírou podpory autonomie ze strany rodičů.

- Vyšší míra explorace a závazku k současnému studiu souvisí s nižším výskytem studijních strachů.

- Nižší výskyt pracovních strachů budou mít ti, kteří mají pracovní poměr, oproti těm, kteří práci nemají.

- Vyšší výskyt pracovních strachů budou mít muži oproti ženám.

- Výskyt pracovních strachů bude nižší u těch, kteří svou práci vnímají jako součást svých kariérních cílů.

- Vyšší výskyt pracovních strachů souvisí s nižší mírou sebeúčinnosti v kariérním rozhodování se, s vyšší mírou rodičovské kontroly a nižší mírou podpory autonomie ze strany rodičů.

- Vyšší míra explorace a závazku $\mathrm{k}$ současné práci souvisí s vyšším výskytem pracovních strachů.

\section{Výzkumný soubor}

Tato studie využívá data, která byla získána v rámci longitudinálního projektu „Cesty do dospělosti“ (Lacinová, Ježek, \& Macek, 2016). Projekt byl realizován výzkumníky z Institutu výzkumu dětí, mládeže a rodiny na Fakultě sociálních studií Masarykovy univerzity v letech 2012-2016. Cílem projektu bylo prozkoumat vývoj autonomie, identity a dalších oblastí u mladých lidí narozených mezi lety 1990-1994. Respondenti byli oslovováni pomocí př́ležitostného výběru, např́klad skrze internet a sociální sít Facebook, v rámci univerzit, středních škol, lokálních televizních vysílání a novin (pro podrobnější popis viz Umemura et al., 2015). Data byla sbírána skrze on-line dotazníky třikrát ročně. Na počátku projektu bylo zapojeno 1057 respondentů, na konci cca 500. Ve vzorku byl od počátku větší počet žen, než mužů, rozdíl v zastoupení obou pohlaví se bohužel s přibývající délkou studie ještě zvyšoval.

Pro analýzu byla použita data ze dvou vln sběru dat. Sběru dat probíhajícího na jaře 2015 se účastnilo 736 respondentů (80,6 \% žen) a sběru dat v prosinci 2015 se zúčastnilo 596 respondentů (83,2 \% žen). Finální vzorek této studie tvoří 303 respondentů, kteří se účastnili obou vln sběru dat a zároveň uvedli odpovědi na otevřenou otázku ohledně strachů a na další použité metody. Jednalo se o 254 žen (83,8 \%) a 49 mužů $(16,2$ \%), průměrný věk souboru byl 24,03 let ( $S D=1,47$; $\min =19,08 \mathrm{max}=32$ let). Většinu respondentů tvořili studenti ( $n=215,71 \%$ ), 198 respondentů uvedlo, že má zaměstnání (65 \%). V základních demografických proměnných se respondenti, kteří jsou součástí finálního vzorku, neliší od původního vzorku. 


\section{Metody}

\section{Strachy; Studijní strachy, Pracovní strachy}

Dotazování, týkající se subjektivně prožívaných strachů, bylo zařazeno na závěr sběru dat na jaře 2015. Jednalo se o otevřenou otázku. Přesná instrukce byla následující: Strach patři k přirozeným emocím, které proživá každý člověk. Můžeme ho znát v mnoha různých podobách-od mírných obav, až po strachy, které mohou člověka zcela ochromit. Nás zajímá, co představuje konkrétně zdroje strachu u vás. Prosíme vás, abyste do následujících políček napsali, čeho se $v$ současnosti bojite. Políček bylo $\mathrm{k}$ dispozici 20. Obdobně jako v předchozí studii (Volková et al., 2016) byly ze získaných strachů vytvořeny kategorie mapující obsahovou stránku strachů. Veškeré odpovědi byly na základě svého obsahu seskupeny do konkrétních kategorií-tento proces probíhal opakovaně, vždy s vyšší úrovní obecnosti. Celý proces kategorizace byl také konzultován s dalšíma dvěma výzkumníky. Výsledkem analýzy byl vznik celkem sedmnácti obecných kategorií. K posouzení reliability bylo provedeno také zařazení jednotlivých výpovědí do těchto kategorií dalším nezávislým posuzovatelem. Jednalo se o ženu (33 let) s psychologickým vzděláním. Měla k dispozici stručný popis kategorií, ke kterým přiřazovala výpovědi respondentů. Shoda posuzovatelů napřič všemi kategoriemi je vysoká $(x=0,88)$, rovněž i shoda pro kategorii pracovních strachů $(x=0,91)$ a studijních strachů $(x=0,94)$ je velmi dobrá.

Studijní strachy byly druhou nejčastěji uváděnou kategorií (po straších o blízké), alespoň 1 studijní strach uvedlo $45 \%$ respondentı̊ $(\mathrm{M}=1,23, \mathrm{SD}=0,51, \mathrm{Min}=1, \operatorname{Max}=4)$. Pracovní strachy byly pátou nejčastěji uváděnou kategorií (po partnerských straších a straších ze selhání). Alespoň jeden pracovní strach uvedlo 34,6 \% respondentů ( $M=1,16$, $\mathrm{SD}=0,46, \operatorname{Min}=1, \operatorname{Max}=4)$. Kategorie studijních a pracovních strachů byly převedeny do dichotomické podoby, která odráží, zda respondent uvedl alespoň jeden strach dané kategorie (1) anebo žádný (0).

\section{Subjektivní vnímání práce a studia}

Respondenti odpovídali na otázky ohledně vlastního hodnocení svého studia a práce. Jednalo se o otázku ve znění: „Vaše (hlavní) práce je: a) Je př́mo součástí mých cílů v oblasti kariéry; b) Je prací, která mi nepř́mo pomůže $v$ dosažení mých cílu v oblasti kariéry; c) Je pouze způsob, jak si v současné době zajistit dostatečný př́ijem; d) Jiné...“. Druhá otázka se týkala studia: „Toto studium považuji za: a) Př́mou přípravu na budoucí povolání b) Nepř́mou součást př́pravy na svoje budoucí povolání; c) Pouze dočasnou aktivitu d) Jiné...“. Obě otázky byly převedeny do dichotomické podoby, která odráží, zda je práce vnímána jako spojená s cíli v oblasti kariéry anebo nikoliv a zda je studium vnímáno jako součást přípravy na budoucí povolání anebo nikoliv $(1=a, b ; 0=c, d)$.

\section{Explorace a závazek $\mathbf{k}$ současnému studiu a práci}

Pro zjištování síly závazku a míry explorace byla použita česká adaptace metody GIDS, Groningen Identity Development Scale (Bosma, 1985). V českém prostředí byla přeložená a aplikovaná v rámci longitudinální studie ELSPAC (European Longitudinal Study of 
Pregnancy and Childhood; Konečná, Neusar, Sokoliová, \& Macek, 2010). V této studii je využita zkrácené verze pro oblast studia a zaměstnání. Sedm položek měří sílu závazku, např.: „Je současné studium pro váš život osobně velmi důležité?") a čtyři položky míru explorace (např.: „Jak často nad svým studiem přmýšlíte?"). Respondenti udávají svůj souhlas $s$ jednotlivými výroky na čtyřbodové Likertově škále ( $1=$ vůbec ne až $4=$ rozhodně ano, často/hodně). Celkový skór míry explorace a závazku je dán jako průměr daných položek pro oblast studia a zaměstnání zvlášt́. Dimenze explorace dosahuje vnitřní konzistence $\alpha=0,611$ pro studium a $\alpha=0,664$ pro zaměstnání a dimenze závazku $\alpha=0,833$ pro studium a $\alpha=0,895$ pro zaměstnání.

\section{Akademické vědomí vlastní účinnosti}

The Academic Self-Efficacy Scale vytvořili Chemers, Hu a Garcia (2001) na základě Bandurovy teorie tak, aby měřila tento koncept ve studijním prostředí. Škála je tvořena osmi výroky, respondenti udávají svůj souhlas s každým z nich na sedmi bodové Likertově škále od 1 (vůbec mě to nevystihuje) do 7 (zcela mě to vystihuje). Česká verze dotazníku byla užita v rámci projektu Cesty do dospělosti (Lacinová, Ježek, \& Macek, 2016). Tito autoři přidali k původním položkám další 4 položky, které měří tento koncept v českém studijním prostředí. $\mathrm{V}$ dotazníku jsou např. tyto položky: „Psaní seminárních prací mi opravdu jde; Umím si dělat poznámky na přednáškách a seminář́ch." Vnitřní konzistence škály $\alpha=0,833$ je uspokojivá.

\section{Sebeúčinnost v kariérním rozhodování se}

V originále Career Decision SelfEfficacy Scale-CDSE, v této studii byla použita zkrácená verze (CDSE-SF) která obsahuje 25 položek (Betz, Klein, \& Taylor, 1996). Česká verze dotazníku byla vytvořena autory týmu Cest do dospělosti (Lacinová, Ježek, \& Macek, 2016). CDSE-SF obsahuje pět subškál: Sebe-posouzení, shromažd’ování informací o povolání, výběr cíle, plánování, a řešení problémů. Respondenti jsou požádáni, aby zhodnotili, do jaké míry si důvěřují v jednotlivých výrocích na pěti bodové Likertově škále od 1 = vůbec si nevěřím do 5 = veř̌ím si). $\mathrm{V}$ dotazníku byly použity například tyto položky: Vybrat si studijní obor nebo povolání, které bude odpovídat vašim zájmům; Udělat si plán svých cílů pro přištích pět let. Celkový skór je dán jako průměr všech položek. Vnitřní konzistence škály je $\alpha=0,936$.

\section{Podpora autonomie a kontrola ze strany rodičů}

Pro zjištování rodičovské podpory a kontroly-pocitované respondenty, byl využit dotazník Perception of Parental Autonomy-Support and Control Scale (Soenens et al., 2007). Ten zjištuje míru vnímané podpory pro autonomii potomka, a naopak míru kontroly potomka, na základě sebedeterminační teorie (viz např. Deci $\&$ Ryan, 2011). Škála se skládá $z 9$ položek pro podporu autonomie a 6 pro kontrolu, tvořených vyjádřením o vztahu s rodičem, se kterými respondenti vyjadřují míru souhlasu na čtyřbodové stupnici od 1 - rozhodně ano, po 4 - rozhodně ne. Metoda byla administrována pro každého rodiče zvlášt. Tvoři ji položky jako například: „Matka/otec mi pomáhá vydat se svou vlastní cestou“, „matka/otec mi ř́ká, jak přesně mám dělat svou práci“. Vnitřní konzistence škály pro oblast kontroly je pro 
matku $\alpha=0,85$ a pro otce $\alpha=0,796$ pro oblast podpory autonomie pak pro matku $\alpha=0,78$ a pro otce $\alpha=0,812$.

\section{Výsledky}

K analýze dat byl použit statistický program IBM SPSS Statistics 24 . Byla provedena vícenásobná logistická regrese na celém souboru respondentů pro predikci výskytu pracovních a studijních strachů na základě vybraných proměnných. Jedná se o dva samostatné modely, pro predikci pracovních strachů a zvlášt pro predikci strachů studijních. Popisné statistiky intervalových proměnných vstupujících do analýz zobrazuje tabulka 1.

Tabulka 1

Popisné statistiky proměnných zařazených do analýz $(N=303)$

\begin{tabular}{lllllll} 
Proměnná & Min & Max & M & SD & Šikmost & Špičatost \\
\hline Akademické vědomí vlastní účinnosti & 1,83 & 6,67 & 4,76 & 0,96 & $-0,49$ & 0,047 \\
\hline Kontrola-matka & 1 & 4 & 3,04 & 0,65 & $-0,70$ & 0,08 \\
\hline Kontrola-otec & 1 & 4 & 3,11 & 0,57 & $-0,88$ & 0,51 \\
\hline Podpora autonomie-matka & 1,22 & 3,67 & 2,03 & 0,45 & 0,81 & 0,24 \\
\hline Podpora autonomie - otec & 1,33 & 4 & 2,20 & 0,51 & 1,03 & 1,31 \\
\hline Explorace-studium & 1,50 & 4 & 2,90 & 0,53 & $-0,15$ & $-0,26$ \\
\hline Závazek - studium & 1 & 4 & 3,20 & 0,54 & $-0,85$ & 0,54 \\
\hline Sebeúčinnost v kariérním rozhodování & 1,32 & 5 & 3,81 & 0,65 & $-0,53$ & 0,33 \\
\hline Explorace - práce & 1,25 & 4 & 2,78 & 0,59 & 0,02 & $-0,29$ \\
\hline Závazek - práce & 1 & 4 & 2,65 & 0,69 & $-0,13$ & $-0,80$
\end{tabular}

Předpoklady pro provedení mnohonásobné logistické regresní analýzy byly naplněny. Pracovní a studijní strachy byly převedeny do dichotomické podoby, dle toho, zda respondent daný strach uvedl (1) anebo ne (0). Do modelu pro predikci studijních strachů bylo zařazeno 303 respondentů. Z nich studijní strach uvedlo 57,1 \% $(\mathrm{n}=173)$ respondentů. V souboru bylo $83,8 \%(n=254)$ žen. $15,2 \%(n=46)$ respondentů uvedlo, že studují při zaměstnání. $91 \%(n=276)$ vnímalo své studium jako přímou či nepřímou přípravu na své budoucí povolání. Model predikuje výskyt studijních strachů lépe, než model nulový $\left(\chi^{2}(10)=31,87, p=0,000\right)$. Úspěšnost predikce výskytu studijních strachů je na základě modelu 62,7 \%, což je zlepšení oproti nulovému modelu, kde byla úspěšnost predikce pouze $43,8 \%$. Podrobné parametry regresního modelu studijních strachů obsahuje tabulka $2 . \mathrm{Z}$ výsledků vyplývá, že významným prediktorem studijních strachů je akademické vědomí vlastní účinnosti, podpora autonomie ze strany otce, závazek $\mathrm{k}$ současnému studiu a pohlaví. Čím vyšší je akademické vědomí vlastní účinnosti a podpora autonomie ze strany otce tím je vyšší šance, že bude uveden studijní strach. Naopak, vyšší závazek k současnému studiu snižuje šanci, že bude uveden studijní strach. Ženy mají vyšší šanci, že uvedou studijních strach než muži. Ostatní prediktory nepřispívají věcně ani statisticky významně $\mathrm{k}$ predikci př́tomnosti studijních strachů. 
Tabulka 2

Proměnné vstupujicí do logistické regrese-studijní strachy

\begin{tabular}{|lllllll} 
& B & S.E. & Wald & P & Exp(B) & 95 \% CI pro Exp(B) \\
\hline Konstanta & $-3,361$ & 1,92 & 3,065 & 0,08 & & \\
\hline Akademické vědomí vlastní účinnosti & 0,47 & 0,17 & 7,59 & 0,01 & 1,60 & $1,14-2,23$ \\
\hline Kontrola-matka & 0,38 & 0,26 & 2,12 & 0,14 & 1,46 & $0,88-2,44$ \\
\hline Kontrola-otec & 0,16 & 0,27 & 0,36 & 0,54 & 1,18 & $0,69-1,99$ \\
\hline Podpora autonomie - otec & 0,83 & 0,31 & 6,89 & 0,01 & 2,28 & $1,23-4,23$ \\
\hline Podpora autonomie-matka & 0,51 & 0,35 & 2,04 & 0,15 & 1,65 & $0,83-3,31$ \\
\hline Explorace ke studiu & $-0,25$ & 0,26 & 0,94 & 0,33 & 0,78 & $0,47-1,29$ \\
\hline Závazek ke studiu & $-0,58$ & 0,30 & 3,58 & 0,05 & 0,56 & $0,31-1,02$ \\
\hline Studují při zaměstnání (0 ne) & $-0,38$ & 0,34 & 1,22 & 0,27 & 0,68 & $0,35-1,34$ \\
\hline Studium cesta k profesnímu cíli (0 ne) & $-0,16$ & 0,48 & 0,11 & 0,74 & 0,85 & $0,33-2,18$ \\
\hline Pohlaví (žena 0) & $-0,90$ & 0,34 & 6,84 & 0,01 & 0,41 & $0,21-0,80$
\end{tabular}

Pozn. Nagelkerke $\mathrm{R}^{2}=0,134$

Do modelu pro predikci pracovních strachů bylo zařazeno 273 respondentů. $\mathrm{Z}$ nich pracovní strach uvedlo 38,5\% $(n=105)$ respondentů. V souboru bylo 82,4 \% $(n=225)$ žen. $65,6 \%(n=179)$ respondentů uvedlo, že má v současné době zaměstnání. 60,1 \% $(n=164)$ vnímalo své zaměstnání jako přímou či nepřímou cestu ke svým profesním cílům. Model predikuje výskyt pracovních strachů lépe než model nulový $\left(\chi^{2}(10)=30,49, p=0,001\right)$. Úspěšnost predikce výskytu pracovních strachů je na základě modelu 82,7 \%, což je zlepšení oproti nulovému modelu, kde byla úspěšnost predikce pouze $61,5 \%$. Podrobné parametry regresního modelu pracovních strachů obsahuje tabulka 3 . $Z$ výsledků vyplývá, že významným prediktorem pracovních strachů je kontrola ze strany otce, závazek k současné práci, zaměstnanost a subjektivní vnímání své práce jako př́mé či nepřímé cesty ke svým profesním cílům. Čím vyšší je závazek k současné práci, tím je vyšší šance, že bude uveden pracovní strach. Naopak, vyšší kontrola ze strany otce snižuje šanci, že bude uveden pracovní strach. Respondenti, kteří mají zaměstnání a také ti, kteří své zaměstnání vnímají jako cestu ke svým profesním cílům, mají nižší šanci, že uvedou pracovní strach než respondenti bez zaměstnání a také ti, kteří své zaměstnání vnímají pouze jako dočasnou aktivitu. Ostatní prediktory nepřispívají věcně ani statisticky významně $\mathrm{k}$ predikci př́tomnosti pracovních strachů.

Tabulka 3

Proměnné vstupující do logistické regrese-pracovní strachy

\begin{tabular}{lllllll} 
& B & S.E. & Wald & P & $\operatorname{Exp}(B)$ & $95 \%$ CI pro $\operatorname{Exp}(B)$ \\
\hline Konstanta & 3,59 & 2,22 & 2,62 & 0,10 & & \\
Sebeúčinnost v kariérním rozhodování & $-0,24$ & 0,23 & 1,10 & 0,29 & 0,78 & $0,50-1,23$ \\
Kontrola-matka & $-0,03$ & 0,28 & 0,01 & 0,92 & 0,97 & $0,56-1,67$ \\
Kontrola-otec & $-0,66$ & 0,30 & 4,78 & 0,02 & 0,52 & $0,29-0,93$ \\
Podpora autonomie - otec & $-0,12$ & 0,34 & 0,12 & 0,73 & 0,89 & $0,45-1,74$
\end{tabular}




\begin{tabular}{|lcccccc|}
\hline Podpora autonomie-matka & $-0,33$ & 0,41 & 0,65 & 0,42 & 0,72 & $0,32-1,60$ \\
\hline Explorace k práci & $-0,23$ & 0,24 & 0,89 & 0,34 & 0,79 & $0,50-1,28$ \\
\hline Závazek k práci & 0,48 & 0,24 & 4,04 & 0,04 & 1,61 & $1,01-2,58$ \\
\hline Zaměstnanost (0 bez práce) & 1,16 & 0,36 & 10,19 & 0,00 & 3,20 & $1,57-6,55$ \\
\hline Zaměstnání cesta k prof. Cíli (0 ne) & 0,66 & 0,29 & 5,32 & 0,02 & 1,94 & $1,11-3,40$ \\
\hline Pohlaví (žena 0) & $-0,44$ & 0,36 & 1,48 & 0,22 & 0,64 & $0,32-1,31$
\end{tabular}

Pozn. Nagelkerke $\mathrm{R}^{2}=0,144$

\section{Diskuze}

Cílem studie bylo prozkoumat možné faktory a charakteristiky, které se vztahují k výskytu subjektivně prožívaných studijních a pracovních strachů $\mathrm{v}$ období třetího decénia. K zvýšení šance výskytu studijních strachů přispívá vyšší míra akademického vědomí vlastní účinnosti, vyšší podpora autonomie ze strany otce a ženské pohlaví. Šanci výskytu studijního strachu naopak snižuje vyšší závazek k současnému studiu. K zvýšení šance výskytu pracovních strachů přispívá vyšší závazek k práci. Šanci výskytu pracovních strachů naopak snižuje pocitovaná kontrola ze strany otce, pracovní úvazek a také zaměstnání, které souvisí s plánovanou profesí respondenta.

Celkově prevalence studijních a pracovních strachů odráží jejich význam pro období třetího decénia, jednalo se o druhou a pátou nejčetnější kategorii. U pracovních strachů by však bylo možné očekávat jejich vyšší umístění v rámci kategorií strachu. Ve studii Ranta, Dietrich a Salmela-Aro (2014) např́iklad obsadily studijní a pracovní strachy první dvě přičky. Nejvyšší četnost strachu o blizké v této studii byla nejspíš zapříčiněna designem studie, kdy dotazování na strachy bylo administrováno na závěr dotazníků zaměřených na vztahy s rodiči. K nižší prevalenci pracovních strachů pak mohla přispět obecnější kategorie strachů ze selhání, do které byly zařazeny například strachy z promarnění života, $\mathrm{z}$ rutiny a stagnace, $z$ nenalezení životního smyslu a z vlastní nedostačivosti či z neschopnosti dosáhnout životních cílů. Tyto strachy pravděpodobně s pracovní oblastí též souvisí, jsou ale obecnější a pravděpodobně obsáhlejší kategorií, byly tedy kategorizovány samostatně a analýza pracovních strachů se jich tak netýkala.

Jedním z potvrzených předpokladi̊ byl vliv pohlaví na výskyt studijních strachů. Ženy skutečně uváděly více studijních strachů než muži, což je v souladu s dalšími studiemi (např. Gullone, 2000; Matud, 2004). V oblasti pracovních strachů byl očekávaný opačný vztah, vyšší prevalence strachů spojených se zaměstnáním je připisována mužům (Matud, 2004). Tento předpoklad potvrzen nebyl, k čemuž mohlo přispět jak nízké zastoupení mužů ve výzkumném souboru, tak také specifikum daného vývojového období. Ženy jsou ve věku, kdy je společností očekáváno, že založí rodinu, a získat vhodné zaměstnání pro ně tak může být v tomto období těžší než pro muže (Valentová, 2004).

Dalšími podpořenými předpoklady byl vztah mezi pracovními strachy a závazkem k práci a opačný vztah mezi studijními strachy a závazkem ke studiu. Pocitovaný závazek $\mathrm{k}$ práci zvyšoval šanci na výskyt pracovních strachů, což může souviset $\mathrm{s}$ vyšší 
zaangažovaností v zaměstnání (Kidd \& Green, 2006). Pravděpodobně se tak zvýší strach ze ztráty zaměstnání a $\mathrm{z}$ vlastního pracovního výkonu, $\mathrm{k}$ čemuž opět může přispět věk respondentů, $k d y$ většina $z$ nich na pracovní trh teprve vstupuje. Mladí lidé tak často mají smlouvu na dobu určitou a své postavení a jistotu si na pracovištích teprve budují. Závazek ke studiu pak naopak snižuje šanci výskytu studijních strachů. Se zvýšeným závazkem ke studiu stoupá studijní spokojenost a jistota (Vijaykumar \& Layanya, 2015), ubývají tak strachy spojené s nedokončením studia či z nevhodné studijní volby.

Částečně byl podpořen předpoklad o vztahu mezi vědomím vlastní účinnosti a strachy. Akademické vědomí vlastní účinnosti zvyšovalo šanci na výskyt studijních strachů, což lze vysvětlit jeho pozitivním vlivem na studijní zaangažovanost, zájem o studium a studijní výsledky (Vuong, Brown-Welty, \& Tracz, 2010). Aktivnější studijní příprava a výkony vedou $k$ vyššímu očekávání výsledků, pravděpodobně se tak zvyšuje strach „ze zkoušek“. Pokud jsou studenti přesvědčeni, že dovedou podat dobrý výkon, je možné, že ho od sebe pak také více očekávají a záleží jim na něm. Sebeúčinnost v kariérním rozhodování se však nepatřila mezi statisticky významné prediktory, což je v rozporu s některými předchozími studiemi (Creed \& Patton, 2003; Rogers, Creed, \& Glendon, 2008). Je možné, že v tomto vývojovém období převážily situační faktory, tedy že bez ohledu na to, jak moc respondenti hodnotí svou schopnost vybrat si a nalézt vhodné zaměstnání, převažuje strach $\mathrm{z}$ handicapů $\mathrm{v}$ podobě chybějící praxe $\mathrm{a} u$ žen již zmíněného věku.

V oblasti pracovních strachů byly dále potvrzeny dva předpoklady ohledně vlivu pracovní zkušenosti a také pracovní zkušenosti, která souvisí s vytyčenými profesními cíly. Obě tyto zkušenosti snižovaly šanci výskytu pracovních strachů. Výsledek je v souladu s dalšími studiemi ohledně pozitivního vlivu pracovní zkušenosti na vývoj pracovní identity a vyšší jistotu v pracovní oblasti, a to bez ohledu na to, zda se jedná o pracovní zkušenost vykonávanou např́klad pouze pro výdělek, anebo pracovní zkušenost, která přímo souvisí se zamýšlenou profesí mladého člověka, i když ta má vliv ještě výraznější (Buhl, 2007; Konstam \& Lehmann, 2011).

V kategorii studijních strachů nebyl potvrzen předpoklad ohledně subjektivního hodnocení studia. Tento výsledek mohl být opět ovlivněn složením výzkumného souboru. Data byla získána na konci longitudinálního výzkumu, jednalo se tedy o respondenty starší, část z nich měla za sebou již změnu studia. Naprostá většina z nich (91 \%) uvedla, že vnímá své studium jako přímou, či nepřímou přípravu na svou budoucí profesi. Díky nízkému zastoupení studentů, kteři své studium hodnotili jako pouze dočasnou aktivitu, nelze vnímat výsledek dostatečně spolehlivě. Potvrzen nebyl ani závěr výzkumu Monsey, Vandehey a Diekhoff (2013) ohledně negativního vlivu zaměstnání při studiu na strachuplnost studentů. Studenti, kteří uvedli, že při svém studiu zároveň dochází do zaměstnání, měli naopak nižší šanci výskytu studijních strachů, tento výsledek však nebyl statisticky významný. Je možné, že výsledek byl ovlivněn tím, že nebylo zjištováno, o jak časově náročnou práci se jedná a nebyla zohledněna ani subjektivně vnímaná náročnost studia.

Posledními prediktory, které měly statisticky významný vliv na výskyt strachů, byla podpora autonomie a kontrola ze strany otce. Výsledky však byly zcela opačné, než bylo 
ve studii předpokládáno. Podpora autonomie ze strany otce vedla ke zvýšení šance výskytu studijních strachů, kontrola ze strany otce naopak snižovala šanci výskytu pracovních strachů. Tento výsledek je zároveň v rozporu se studiemi zabývajícími se vztahy s rodiči (Desjardins \& Leadbeater 2017; Schulman, Hakhmigari, Michaeli, Tuval-Mashiach, \& Dickson, 2016). Ve studii Desjardins a Leadbeater (2017) však zároveň vyšší rodičovská podpora vedla $k$ vyšší nezaměstnanosti a u dívek také $\mathrm{k}$ tomu, že si více říkaly o pomoc a méně řešily problémy samy. Podpora i kontrola ze strany matky byla v rámci výzkumného souboru rovnoměrněji rozložená, u podpory a kontroly ze strany otce byly rozdíly mezi respondenty výraznější, což pravděpodobně ovlivnilo výsledek. Z otázek dotazníku je patrné, že vyšší podpora autonomie je spojena také s vyšším zájmem ze strany rodiče. Je tedy možné, že respondenti, kteří vnímají vyšší podporu autonomie ze strany otce tak nechtějí svého rodiče zklamat a více jim tak na studiu záleží, což se může podepsat v podobě vyššího výskytu studijních strachů. Vyšší kontrola ze strany otce je spojena $\mathrm{s}$ nízkým delegováním zodpovědnosti směrem $\mathrm{k}$ dítěti-rozhodnutí činí rodič, potomek má poslouchat. Je tedy možné, že se tento vztah promítá i do kariérního rozhodování, které je ponecháno na rodiči. Potomek pak půjde tam, kam mu bude doporučeno, zodpovědnost za rozhodnutí není na jeho straně. Tento postoj by pak mohl vést ke snížení šance výskytu pracovních strachů, neb ty jsou vlastně zčásti zbytečné. Ve výzkumu Schulmana s kolektivem (2016) vyšší kontrola ze strany rodičů byla spojena s nízkou explorací a závazkem v pracovní oblasti, je tedy možné, že nízký výskyt pracovních strachů tento stav reflektuje.

Co se týče aplikačního potenciálu zjištění vycházejících $\mathrm{z}$ předkládané práce, nabízí se prostor zejména $\mathrm{v}$ kariérním poradenství. Konkrétně doporučení $\mathrm{k}$ podpoře studentů k aktivnímu hledání pracovních zkušeností, a to i těch mimo svůj zamýšlený obor. Zdá se, že pracovní zkušenost pomáhá nejen vyjasnit vlastní pracovní preference, ale současně snižuje strach ze správné pracovní volby. Dále je možno podpořit rodiče mladých lidí, aby jim v otázce kariérního směřování nechávali větší volnost, a to i přesto, že povede například ke zvýšení prožívaného strachu a nejistoty. Jak již bylo řečeno, zdá se, že prožívané strachy ve studijní a pracovní oblasti jsou pro mladé lidi také motivační, a tak mohou být prospěšné. Pokud se tedy rodiče naopak snaží své děti v těchto oblastech co nejvíce podpořit a kontrolovat-ve smyslu učinit volbu a výběr za ně, či saturovat jim finanční prostředky, dokud si sami něco vhodného nenajdou, může to být naopak kontraproduktivní. Jak v oblasti studia, tak zaměstnání platí, že zkušenost a aktivita tyto strachy snižuje.

\section{Limity studie}

Limitem současné studie je složení výzkumného souboru. Jedná se zejména o již zmíněný problém s významnou převahou žen v souboru, dále s převahou studentů a respondentů spíše starší věkové kategorie. Jako problematický lze hodnotit též design studie, kdy otevřená otázka ohledně výskytu strachů byla zařazena až na závěr skupiny dotazníků, které byly zaměřené na vztahy mladých lidí s jejich rodiči. Tento fakt mohl ovlivnit kognitivní rámec respondentů a způsobit tak vyšší uvedení strachů o blízké, než je pro 
dané věkové období na základě obdobných studií očekávatelné (např. Ranta, Dietrich, \& Salmela-Aro, 2014; Volková et al., 2016).

Určitý limit představuje i zvolená metoda použitá ke zjištování strachů. Na základě předchozí zkušenosti (Volková et al., 2016) byla záměrně zvolena pouze otevřená otázka, ohledně výskytu strachů, která vhodně zachycuje skutečnou podobu specifických strachů, na rozdíl např. od předem připravených inventářủ strachů. Při použití této metody je však očekávatelné, že vztahy mezi proměnnými budou statisticky slabé. Limit současné studie spočívá i ve využití dat pouze ze dvou krátce po sobě jdoucích časových úseků. Nelze se tedy zaměřit na kauzalitu mezi proměnnými.

V současné studii byly blíže zkoumány prediktory, které se na základě empirických studií vážou jak k pracovní, tak studijní oblasti. Vzhledem k poměrně malému rozptylu studijních a pracovních strachů vysvětlených v rámci této studie, je jasné, že existují další faktory, které mají na výskyt studijních a pracovních strachů podstatný vliv. To jsou možnosti dalšího zkoumání.

\section{Závěr}

Výskyt studijních a pracovních strachů dobře reflektuje vývojové úkoly typické pro období třetího decénia, studie napomohla $\mathrm{k}$ lepšímu pochopení studijních a pracovních strachů. Výskyt těchto strachů nelze hodnotit pouze jako známku vnímaných problémů v rámci pracovní a studijní oblasti, odráží zároveň i zvýšenou motivaci a zájem o danou oblast. Výskyt studijních a pracovních strachů lze tedy chápat jako pozitivní ukazatel normativnosti vývoje. Zajímavé je srovnání studijní a pracovní oblasti, vývoj studijní identity je v tomto období výrazně delší, zdá se tedy, že jsou mladí lidé v této oblasti celkově jistější. $Z$ výsledků studie vyplývá, že výskyt studijních strachů je více spojen s vnímáním a hodnocením vlastních studijních schopností (vědomí vlastní účinnosti) a studijním závazkem. Více studijních strachů také vykazují ženy než muži. V pracovní oblasti se jako nejsilnější prediktor, snižující šanci výskytu pracovních strachů, projevila získaná pracovní zkušenost. V rámci pracovních zkušeností měla nejsilnější vliv zkušenost se zaměstnáním, které je spojené s profesním cílem. $Z$ výsledků tak vyplývá, že pracovní jistota je teprve budována a konkrétní pracovní zkušenost je v tomto procesu podstatná. Vnímání a hodnocení vlastních schopností nemělo na výskyt pracovních strachů významný vliv. Zajímavý je vztah mezi vnímanou podporou a kontrolou autonomie ze strany otce a oblastí strachů. Vyšší podpora autonomie ze strany otce zvýšila šanci výskytu studijních strachů, což může být dáno vyšší vnímanou odpovědností za studium a strachem $\mathrm{z}$ toho, rodiče zklamat. Vyšší otcovská kontrola naopak snižovala výskyt pracovních strachů, což lze vysvětlit sníženou odpovědností ohledně rozhodnutí v pracovní oblasti a celkově nižší motivací pracovní oblastí se zabývat. 


\section{Reference}

Bandura, A., Barbaranelli, C., Caprara, G.V., \& Pastorelli, C. (2001). Self-efficacy beliefs as shapers of children's aspirations and career trajectories. Child development, 72(1), 187-206. https://doi. org/10.1111/1467-8624.00273

Bandura, A. (1997). Self-efficacy: The exercise of control. New York: Freeman.

Betz, N. E., \& Hackett, G. (1986). Applications of self- efficacy theory to understanding career choice behaviour. Journal of social and clinicalpsychology, 4(3), 279-283. http://dx.doi.org/10.1521/ jscp.1986.4.3.279

Betz, N. E., Klein, K., \& Taylor, K. M. (1996). Evaluation of a short form of the Career Decision Self-Efficacy Scale.Journal of Career Assessment, 4,47-57.http://dx.doi.org/10.1177/106907279600400103

Bosma, H. A. (1985). Identity development in adolescents: Coping with commitments. Unpublished doctoral dissertation. Groningen: University of Groningen.

Bosma, H. A., \& Kunnen, E. S. (2001). Determinants and mechanisms in ego identity development: A review and synthesis. Developmental Review, 21,39-66. http//dx.doi.org/10.1006/drev.2000.0514

Buhl, H. M. (2007). Well-Being and the Child-Parent Relationship at the Transition from University to Work Life. Journal of Adolescent Research, 22, 550-571. http://dx.doi.org/10.1177/0743558407305415

Creed, P., \& Patton, W. (2003). Predicting Two Components of Career Maturity in School Based Adolescents. Journal of Career Development, 29(4), 277-290. http://dx.doi.org/10.1023/A:1022943613644

Deci, E. L., \& Ryan, R. M. (2011). Self-determination theory. In P. A. M. Van Lange, A. W. Kruglanski, \& E. T. Higgins (Eds.), Handbook of theories of social psychology (s. 416-433). Thousand Oaks: SAGE Publications.

Desjardins, T., \& Leadbeater, B. J. (2017). Changes in parental emotional support and psychological control in early adulthood: Direct and in direct associations with educational and occupational adjustment.; Emerging Adulthood, Vol 5(3), 177-190. http://dx.doi.org/10.1177/2167696816666974

Gardner, S., \& Eng, S. (2005). What Students Want: Generation Y and the Changing Function of the Academic Library. Portal: Libraries, 5(3), 405-420. http://dx.doi.org /10.1353/pla.2005.0034

Gullone, E. (2000). The development of normal fear: A century of research. Clinical Psychology Review, 20(4), 429-451. https://doi.org/10.1016/s0272-7358(99)00034-3

Gullone, E., \& King, N. J. (1993). The fears of youth in the 1990s: Contemporary normative data. The Journal of Genetic Psychology, 154, 137-153. http://dx.doi.org/10.1080/00221325.1993.9914728

Hejlová, H. (2005). Vnímání ohrožujících jevů dětmi. Pedagogika, 55, 119-137.

Chemers, M. M., Hu, L., \& Garcia, B. F. (2001). Academic Self- Efficacy and First-Year College Student Performance and Adjustment. Journal of Educational Psychology, 93(1), 55-64. http://dx.doi. org/10.1037/0022-0663.93.1.55

Chow, A., Galambos, N. L., \& Krahn, H. J. (2017). Work values during the transition to adulthood and mid-life satisfaction. International Journal of Behavioral Development, 41(1), 105-114. https://doi. org/10.1177/0165025415608518

Kenny, M. E., \& Sirin, S. R. (2006). Parental attachment, self-worth, and depressive symptoms among emerging adults. Journal of Counselling and Development, 84, 61-71. http://dx.doi.org/ 10.1002/j.1556-6678.2006.tb00380.x

Kidd, J. M., \& Green, F. (2006). The careers of research scientists: predictors of three dimensions of career commitment and intention to leave science. Personnel review, 35(3), 229-251. http://dx.doi. org/10.1108/00483400610656676

King, N. J., Kolier, K., Iacuone, R., Schuster, S., Bays, K., Gullone, E., \& Ollendick, T. H. (1989). Child and adolescent fears: An Australian cross-sectional study using the Revised Fear Survey Schedule for Children. Journal of Child Psychology and Psychiatry, 30, 775-784. https://doi. org/10.1111/j.1469-7610.1989.tb00789.x 
Konečná, V., Neusar, A., Sokoliová, M., \& Macek, P. (2010). Možnosti zkoumání formování identity v adolescenci: česká adaptace metody GIDS. Československá psychologie, 54(4), 391-406.

Konstam, V., \& Lehmann, I. S. (2011). Emerging Adults at Work and at Play: Leisure, Work Engagement, and Career Indecision. Journal of Career Assessment, 19(2), 151-164. http://dx.doi.org/10.1177/ 1069072710385546.

Lacinová, L., Ježek, S., \& Macek, P. (2016). Cesty do dospělosti: Psychologické a sociální charakteristiky dnešních dvacátníků (1. vyd). Brno: MUNI Press.

Marcia, J. E. (1993). The ego identity status approach to ego identity. In J. E. Marcia, A. S. Waterman, D. R. Matteson, S. L. Archer, \& J. L. Orlofsky (Eds.), Ego identity: A handbook for psychosocial research (s. 1-21). New York: Springer-Verlag.

Matud, M. (2004). Gender differences in stress and coping styles. Personality and Individual Differences, 37, 1401-1415. http://dx.doi.org/10.1016/j.paid.2004.01.010.

Michalčáková, R. (2007). Strachy v obdobi rané adolescence. Brno: Barrister \& Principal.

Mounsey, R., Vandehey, M., \& Diekhoff, G. M. (2013). Working and non-working University Students: Anxiety, Depression, and grade point average. College Student Journal, 47(2), 379-389.

Muris, P., Meesters, C., \& Knoops, M. (2005). The Relation Between Gender Role Orientation and Fear and Anxiety in Nonclinic-Referred Children. Journal of Clinical Child \& Adolescent Psychology, 34(2), 326-332. doi:10.1207/s15374424jccp3402_12

Muris, P., Merckelbach, H., Ollendick, T., King, N., Meesters, C., \& van Kessel, C. (2002). What is the Revised Fear Survey Schedule for Children measuring? Behaviour Research and Therapy, 40, 1317-1326. https://doi.org/10.1016/0005-7967(91)90134-O

Porfeli, E. J., $\&$ Lee, B. (2012). Career development during childhood and adolescence. New direction for youth development, 134, 11-21. http://dx.doi.org/10.1002/yd.20011

Ranta, M., Dietrich, J., \& Salmela-Aro, K. (2014). Career and Romantic Relationship Goals and Concerns During Emerging Adulthood. Emerging Adulthood, 2(1) 17-26. https://doi. org $/ 10.1177 / 2167696813515852$

Rogers, M. E., Creed, P. A., \& Glendon, A. I. (2008). The role of personality in adolescent career planning and exploration: A social cognitive perspective. Journal of Vocational Behaviour, 73, 132-142. http://dx.doi.org/10.1016/j.jvb.2008.02.002

Shulman, S., \& Ben-Artzi, E. (2003). Age-related differences in the transition from adolescence to adulthood and links with family relationships. Journal of Adult Development, 10, 217-226. http:// dx.doi.org /10.1023/A:1026006025155

Shulman, S., Hakhmigari, M. K., Michaeli, Y., Tuval-Mashiach, R., \& Dickson, D. J. (2016). Achieving work and love authorship in emerging adulthood: Types, psychosocial correlations, and precursors. Emerging Adulthood, 4(4), 258-271. https://doi.org/10.1177/2167696815606563

Soenens, B., Vansteenkiste, M., Lens, W., Luyckx, K., Goossens, L., Beyers, W., \& Ryan, R. M. (2007). Conceptualizing parental autonomy support: Adolescent perceptions of promotion of independence versus promotion of volitional functioning. Developmental Psychology, 43(3), 633-646. https://doi.org/10.1037/0012-1649.43.3.633

Valentová, M. (2004). Rovnováha mezi rodinným životem a pracovni kariérou v kontextu ženské zaměstnanosti. Mezinárodní srovnávací studie. Praha: VÚPSV

Vijaykumar, S. D., \& Lavanya, T. (2015). Vocational Identity and Ego Strengths in Late Adolescence. Journal of Business Studies \& Research, 1, 52-59.

Volková, A. (2015). School fears among czech undergraduate students. In: International technology, education and development conference (INTED 2015). Valencia: IATED, 2015, s. 3525-3530.

Volková, A., \& Dušková, P. (2015). Specific Fears in Emerging Adulthood among Czech Undergraduate Students. Procedia - social and behavioral sciences. (171), 487-493. https://doi.org/10.1016/j. sbspro.2015.01.151 
Volková, A., Lacinová, L., Neužilová Michalčáková, R., \& Dušková, P. (2016). Čeho se dnes mladí lidé bojí? Volně generované výpovědi o strachu vs. sebeposuzovací škála. Československá psychologie, 60(2), 197-210.

Vuong, M., Brown-Welty, S., \& Tracz, S. (2010). The effects of self- efficacy on academic Access of firs-generation college ophomore students. Journal of college students development, 51(1), 50-64. http:// dx.doi.org /10.1353/csd.0.0109

Weier, M., \& Lee, Ch. (2016). Stagnant or Successful, Care free or Anxious? Australian University Students' Goals and Beliefs About Adulthood and Their Current Well-being. Australian Psychologist, 51(6), 422-430. http://dx.doi.org/10.1111/ap.12169

Korespondenčná autorka: Lenka Lacinová, Institut výzkumu dětí, mládeže a rodiny, Katedra psychologie, Fakulta sociálních studií, Masarykova univerzita v Brně, Joštova 10, 60200 Brno, Česká republika. Email: lacinova@fss.muni.cz

A. Kohoutová, L. Lacinová (2020). Studijní a pracovní strachy mladých dospělých. Psychologie a její kontexty, 11(1), 69-87. https://doi.org/10.15452/PsyX.2020.11.0005 